\title{
Implementation of School Health Unit in a Elementary School
}

\author{
Ali Umar *, Ivan Adhi Purbaya \\ Sport Education Program \\ Faculty of Sport Education and Health \\ Padang State University \\ Padang, Indonesia \\ *buyaaliumar@gmail.com
}

\begin{abstract}
This research aims to examine the implementation of the school health program in North Padang Elementary School. This type of research is descriptive, involving 18 schools. The research instrument used a questionnaire. The analysis technique used frequency distribution techniques or techniques percentage, implementation of health education in Padang Utara Elementary School by $\mathbf{7 9 . 5 5 \%}$ in the classification "good." Implementation of health services in North Padang Elementary School by $\mathbf{7 0 . 6 6 \%}$ in the classification "good." Implementation of healthy school environment development in North Padang Elementary School by $85.47 \%$ in the classification of "very good." Implementation of the school health program in North Padang Elementary School as a whole amounted to $79.23 \%$ in the classification "good."
\end{abstract}

\section{Keywords-Implementation of School Health Unit}

\section{INTRODUCTION}

Education conducted in Indonesia in every type and level of education should refer to the achievement of the functions and objectives of the national education. National education is education that is based on Pancasila and the Constitution of the Republic of Indonesia Year 1945 rooted in religious values, national culture of Indonesia and responsive to the changing demands of the times [1].

In connection with the function and purpose of national education at the top, one of the goals of national education is concerned about learners in order to become a healthy human. "One of the goals of education in Indonesia is to disseminate information that is educational and skills that are useful and practical, so that development continues danseluruh people can live in a decent and healthy habits" [2]. Schools can be said a cultural institution and nation builder. One result of human culture should be fostered and developed as the nation's culture, both in the family and at school is a healthy life [3].

School occupies a strategic position in health promotion efforts, because: a) the majority of children aged 5-19 years exposed to the educational institutions in the time period long enough (kindergarten through high school); b) school support growth and natural development of a child, because at school a child can learn a variety of knowledge, including health, as a provision for later life.

Various studies have shown that school health promotion proved effective enough to improve the health of students, teachers, and staff and quality facilities to support teaching and learning. One study shows that health promotion efforts at a primary school in Ife District, Northwest Nigeria conducted in the period of 2002-2005 succeeded in improving the quality of school buildings, reducing the density in the classroom, increase the supply of clean water, improved hygiene and maintenance of facilities, food hygiene, and behavior of students in the trash [4].

There are two important issues of health promotion programs in schools, namely: a) in relation to the benefits; and b); related to the objectives, methods and techniques [4]. In terms of benefits, health promotion in schools to participate and build a healthy young man physically, mentally, morally and intellectually, as well as supplying them with berkehidupan skills (life skills) are very important in later life cover. As related to objectives, methods, and techniques, health promotion in schools is very strategic and favorable review of aspects of the population, aspects of the development of the individual, and organizational aspects.

Of the important things above, school health is very strategic and has benefits for young people to dikehidupannya later, and the passage of health in schools one of them also from the aspect of the organization. Health organizations at the school already available institutions to implement them, the program School Health Unit (UKS). School Health organized to enhance the ability of learners in healthy living healthy living environment so that students learn, grow and develop in harmony and become the highest-quality human resources [5].

The general objective of the program School Health Unit (UKS) is improving the ability of school children clean and healthy living behavior, improving health status and create a healthy environment, so as to enable the growth and development of harmonious and optimal. Health care will be better than the treatment [6].

UPTD North Padang District is one UPTD located in the city of Padang, in total there are 23 State Primary School status which mostly have had school health organization that School Health Unit (UKS). Based on the availability of school health organizations, should be in the implementation of the UKS in school can be carried out as it should. However, from the observations of researchers in one public elementary school in the district of Padang Utara that the implementation of the UKS not been implemented as expected, seen from space UKS into the rooms of the library, funds for UKS seems not to be taken seriously so that the completeness of health that should be in the infirmary such drugs are not available.

Many students do not have an awareness of environmental hygiene with the litter so that the school yard 
looks dirty, WC learners are not noticed by the school, the water in the toilet was not clean as well as bottles of water in the bathtub, the state of the toilet is dirty and smelly because after urination students are rarely straight flush, and soils of shoes students to come in so that littered the floor, not infrequently also if there are students who are sick at school, the students are immediately told to go home without any examination or service beforehand indoors UKS, no teacher who manages the school health program, and teachers do not provide health services to students with student checking hygiene routine and unscheduled.

From the real problems of the above, could be described either Elementary School North existence Padang in Padang for the implementation of the school health program has not been implemented as expected. These problems made to examine the entire implementation of the School Health Unit in Padang Utara Elementary School.

\section{RESEARCH METHODOLOGY}

Type of this research is descriptive research. The population in this study are all Padang Utara Elementary School amounting to 23 schools. Mechanical withdrawal of the sample using purposive sampling technique [7] that the State Elementary School located in Padang Utara and have a school health program. The research instrument used questionnaire. Data analysis techniques using percentages by the formula:

$$
p=\frac{F}{n} \times 100 \%
$$

\section{RESULTS}

\section{Health Education}

Health education research results obtained from 18 respondents, of grain research statement can be seen in the table below:

According to the table above were obtained as much as $1.48 \%$ of respondents get a score (1), a total of $5.56 \%$ of respondents earn score (2), then as much as $16.30 \%$ of respondents got a score of (3), as much as $47.04 \%$ of respondents earn score (4), and $29.63 \%$ of respondents earn score (5)

\section{Health Services}

Health services research results obtained from 18 respondents, of grain research statement can be seen in the table below:

According to the table above were obtained as much as $5.56 \%$ of respondents get a score (1), as much as $11.67 \%$ of respondents earn score (2), then as much as $23.89 \%$ of respondents got a score of (3), as much as $37.22 \%$ of respondents earn score (4), and $21.67 \%$ of respondents earn score (5)

\section{Fostering Healthy School Environment}

Environmental development research results obtained from 18 respondents, of grain research statement can be seen in the table below:

According to the table above were obtained as much as $0.85 \%$ of respondents get a score (1), a total of $3.42 \%$ of respondents earn score (2), then as much as $8.97 \%$ of respondents got a score of (3), as much as $41.03 \%$ of respondents earn score (4), and $45.73 \%$ of respondents earn score (5).

\section{Implementation of School Health Program in North Padang Elementary School in Overall}

Implementation of the research results of the school health program in North Padang Elementary School obtained from 18 respondents, of grain research statement can be seen in the table below:

According to the table above were obtained as much as $2.36 \%$ of respondents get a score (1), a total of $6.48 \%$ of respondents earn score (2), then as much as $15.78 \%$ of respondents got a score of (3), as much as $42.41 \%$ of respondents earn score (4), and $33.08 \%$ of respondents earn score (5).

\section{DISCUSSION}

\section{Health Education}

Health education are: Health education is efforts exerted in the form of guidance to learners about health covers all aspects of personal health so that his personality can grow and develop well through curricular and extracurricular activities [4].

Obtained score ultimate answer is the answer score of "4" with alternative answers "often" reached a score of 127. This means that of the 15-point declaration was given to 18 respondents, more respondents chose the answer score of "4". So that means health education activities in Padang Utara Elementary School are conducted frequently. While the score is the lowest response on answer score of "1" with an alternative answer "never" achieved a score of 4. This means that the respondent few choose alternative answer is never, which means never to not conduct health education activities.

Based on the results of the study, found the number of SC (score achievement) Health Education is 1074. With a score of achievements for 1074 the percentage of implementation of Health Enterprises Padang Utara Elementary School based Health Education Indicators reached $79.55 \%$. Thus, categorized GOOD.

\section{Service Health}

Health services namely health services in schools / madrasah is an effort to increase (promotion), prevention (preventive) treatment (curative), and recovery (rehabilitation), performed on learners and the environment [4].

Obtained score ultimate answer is the answer score of "4" with alternative answers "often" reached a score of 67. This means that of the 10-point declaration was given to 18 respondents, more respondents chose the answer score of "4". So that means the activities of health services in North Padang Elementary School are conducted frequently. While the score is the lowest response on answer score of "1" with an alternative answer "never" achieved a score of 10. This means that the respondent few choose alternative answer is never, which means never to not perform activities of health services.

Based on the results of the study, found the number of SC (score achievement) Health Care is 636. With a score of 
636 then the percentage achievement Implementation of Health Enterprises Padang Utara Elementary School based health service indicator reached $70.66 \%$. Thus, categorized GOOD.

\section{Development of Healthy School Environment}

Fostering a healthy school environment is: The attempt to create environmental conditions schools to support the educational process so as to achieve optimum results both in terms of knowledge, skills and attitudes [8].

Obtained score ultimate answer is the answer score of "5" with alternative answers "very often" reached a score of 107. This means that of the 13-point declaration was given to 18 respondents, more respondents chose the answer score of "5". So that means coaching activities sehatdi school environment Padang Utara Elementary School are conducted very often. While the score is the lowest response on answer score of "1" with an alternative answer "never" achieved a score of 2 . This means that the respondent few choose alternative answer is never, which means never to not engage in activities fostering a healthy school environment.

Based on the results of the study, found the number of SC (score achievement) Fostering Healthy School Environment is 1000 . With a score achievements of 1000 the percentage of implementation of the State Primary School Health Unit Padang Utara based healthy school environment development indicators reached $85.47 \%$. Thus, categorized EXCELLENT.

\section{Implementation of School Health Program in North Padang Elementary School in Overall}

School health program are: All efforts were made to improve the health of school age children at each track, the type and level of education from kindergarten / RA, Elementary, Junior SMA / SMK / MA / MAK. Health of the School of Business is also part of public health carried on in schools [4].

Obtained score ultimate answer is the answer score of "4" with alternative answers "often" reached a score of 290. This means that of the 38 point declaration implementation of school health efforts given to 18 respondents, more respondents chose the answer score of "4". So that means the activities of implementation of the school health program in North Padang Elementary School are conducted frequently. While the score is the lowest response on answer score of "1" with an alternative answer "never" achieved a score of 16. This means that the respondent few choose alternative answer is never, which means never to not perform activities of implementation of the school health program in Primary Schools Negeri Padang Utara.

Based on the results of the study, found the number of SC (score achievement) Implementation of Elementary School Health Enterprises Padang Utara is 2710. With a score of achievement by 2710 the percentage of implementation of the State Primary School Health Unit Padang Utara In Overall reached $79.23 \%$. Thus, categorized GOOD.

\section{CONCLUSION}

Based on the results of research that has been described, can be summarized as follows. 1). Implementation of Health Education attainment levels by $79.55 \%$. That means being on the classification of "GOOD". 2). The level of implementation achievements of Health Services amounted to $70.66 \%$. That means being on the classification of "GOOD". 3). The level of implementation achievements HEALTHY Educational Development Environment for $85.47 \%$. That means being on the classification of "EXCELLENT". 4). Health Enterprises capaianPelaksanaan Level Elementary School Sekolahdi Padang Utara amounted to $79.23 \%$. That means being on the classification of "GOOD".

\section{REFERENCES}

[1] Law on National Education System (UUSPN) number 20 of 2003

[2] Tonny Sadjimin and Peter Whiticar. "Guidelines for School Health and Masyarakat".Yogyakarta: Essentia Medica Foundation. 1979

[3] M. Ichsan. "Health Education and Sports". Jakarta: Ministry of Education. 1988

[4] Notoatmodjo, Soekidjo, et al. "Health Promotion in the School”. Jakarta: Rineka Reserved. 2012.

[5] Law on Health No. 36 Year 2009

[6] Rosmanelli, FU, Yaslindo, FU, \& Kibadra, FU. "Implementation Assessment Elementary School Health Enterprises In South Coastal District". J. Menssana Vol. 4 No. 1,pp 39-43. 2019

[7] Arikunto, Suharsimi. "Research Procedure, A Practical Approach". Jakarta: Rineka Reserved. 2014, pp, 45-46

[8] Ministry of Education and Kebudayaan. "UKS School Guidelines". Jakarta: Directorate General of Primary Education. 2014, 20-21 